\title{
FACTORS AFFECTING THE SATISFACTION OF BUSINESSES USING ONLINE TAX PAYMENT SERVICES AT THE TAX DEPARTMENT OF HO CHI MINH CITY, VIETNAM
}

\author{
Ai Huu Tran \\ Dao Mai Thi Hong \\ Van Hien University, Ho Chi Minh, Vietnam \\ Thanh Vinh Bui \\ Vietinbank, Tay Tien Giang Branch, Vietnam
}

Customer satisfaction forms the foundation of any business success, as it leads to service reuse, brand loyalty and positive word of mouth. This study has been conducted as a survey. Convenient sampling method has been applied on a sample of 300 enterprises that have been using online tax payment services of the Tax Department of Ho Chi Minh City. The research model parameters include: (1) Information and system quality, (2) Time efficiency, (3) Confidentiality of information and transactions, (4) Support service / customer service, (5)

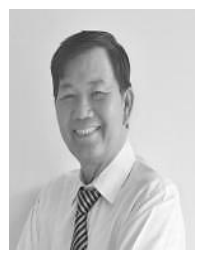

\section{Ai Tran Huu}

Ph.D, Lecturer of Faculty of Economics, Van Hien University, Ho Chi Minh City, Vietnam.

Research interests: markets of agricultural products; SMEs functioning with government support; organic food markets; environmental issues of economic development; corporate social responsibility.

E-mail: aith@vhu.edu.vn

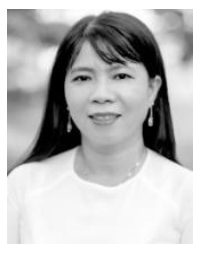

\section{Dao Mai Thi Hong}

ME, Lecturer at the Faculty of Economics, Van Hien University, Ho Chi Minh City, Vietnam.

Research interests: SMEs functioning under government support; consumer behavior; innovative products.

E-mail: daomth@vhu.edu.vn

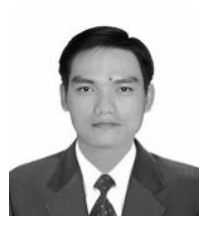

\section{Bui Vinh Thanh}

MBA, Director at VietinBank, Tay Tien Giang Branch.

Research interests: SMEs functioning under government support; consumer behavior; innovative products.

E-mail: bvthanh@vietinmabk.vn 


\section{FACTORS AFFECTING THE SATISFACTION OF BUSINESSES}

Helpful awareness, (6) Trust in tax authorities. The results show that confidentiality of information and transactions has the strongest impact. Trust in tax authorities and Helpful awareness impact goes second. Next is time efficiency and support service/customer service. Finally, the Information and system quality is ranked the last one since it has the lowest beta coefficient.

Keywords: satisfaction with a service; online tax payment service; tax department; Ho Chi Minh; Vietnam.

\section{Introduction}

Many studies have already looked at the effects of customer satisfaction on service reuse, satisfaction and retention. Many researchers point to the fact that happy customers share their experiences with others, on average, about five to six people. In contrast, dissatisfied customers are more likely to tell at least ten other people about their unfortunate experience with a product or a service. Customer satisfaction is the result perceived by the people who have experienced company's performance. Many researchers and scholars emphasize the importance of customer satisfaction since the latter has a direct and immediate positive effect on profitability.

Several previous studies on online tax services have looked at people's satisfaction through a number of criteria such as convenience, ease of use, quality of service, reliability and risk-taking.

A study by Abhichandani \& Horan (2006) found that, in business, $67 \%$ of customers use a website to search for information, $61 \%$ buy goods online, while in e-government, $83 \%$ use the website to gather government information and $66 \%$ use the web to complete government transactions. If citizens cannot complete government-related transactions online, they will be discouraged and this will reduce the "use of e-government services" in the future. Research shows that the search for government-related information is quite a frequent phenomenon, while government electronic service interaction is still rather limited. Thus, it is necessary to assess whether citizens are satisfied when participating in e-government services provision (Barnes \& Vidgen, 2006). Interaction, in this case, means the process of how the government focuses on performing its work and this includes such parameters as the time to complete an activity, sending and receiving e-mails from government authorities, etc.

Vietnam is gradually shifting to a serving administrative system to meet the requirements of renovation and international integration. In this context, customer satisfaction with public administrative services is the target and also a measure of performance for all state administrative agencies. At the same time, the tax policy formulation needs to be compatible with tax administration, ensuring both internationalization and modernization which together assume creating a favorable business environment, able to attract domestic and foreign investments.

Therefore, introduction of information technologies in tax administration is becoming extremely important as it contributes to adaptability of domestic and foreign businesses, as well as to improved service quality, quicker service supply and convenience in provision of tax information for all taxpayers. Online tax declaration and electronic tax payments are the most advanced trends of today as they provide a breakthrough in administrative procedures and gradual modernization of taxation as such. 
Therefore, taxpayers' satisfaction assessment is an integral part of administrative reforms planning and implementation in all tax agencies. Raising taxpayers' satisfaction with online services provided by tax authorities is essential for the tax industry as this helps tax agencies adjust to the demands of current times, build a truly quality system, be overall reliable, fast and safe and thus — meet the requirements of ISO 9001: 2008 standard.

\section{Theoretical basis}

Business (corporate customer) satisfaction is very different from consumer (individual customer) satisfaction when it comes to typical service usage scenarios. The use of enterprise/corporate products/services is often more about planning, money and risk rather than actually dealing with customers face-to-face. Satisfaction is "the response to the difference between feeling and expectation" (Parasuraman et al., 1988). Research conducted back in 2004 on satisfaction by Delone \& McLean has shown that "customer satisfaction is an important means of measuring customer views about the online service system they are using". According to Cronin \& Taylor (1992) customer satisfaction with online services is the customer's internal feelings about past activities and online service experiences online. Similar to individual customer satisfaction, institutional (corporate) customer satisfaction is usually focused on assessing the satisfaction of the "key informants".

Service quality is a concept that has been heavily debated by scholars because of the difficulties with defining and measuring it. Measuring service quality might be also difficult due to its own characteristics: intangibility, heterogeneity, and indissolubility (Barnes, 2006), suggested that customer satisfaction should be assessed in a short time, while service quality should be assessed according to customer attitudes about that service over a longer period of time.

Table 1 - Components of service quality under SERVQUAL model

(Source: Parasuraman et al., 1988)

\begin{tabular}{|c|l|c|}
\hline Components & \multicolumn{1}{|c|}{ Definition } & $\begin{array}{c}\text { Observed } \\
\text { variables (22) }\end{array}$ \\
\hline Credibility & $\begin{array}{l}\text { The ability to perform the promised service reliably and } \\
\text { accurately }\end{array}$ & 4 \\
\hline Visibility & $\begin{array}{l}\text { Physical conditions, equipment and appearance of service } \\
\text { staff }\end{array}$ & 4 \\
\hline $\begin{array}{c}\text { Responsivene } \\
\text { ss }\end{array}$ & Willingness to help customers and provide prompt service & 4 \\
\hline Guarantee & Knowledge and manners of service staff & 5 \\
\hline Empathy & Personal attention to each customer & 5 \\
\hline
\end{tabular}

According to Haywood-Farmer (1998), before using the service, the customer has formed a "scenario" of that service. Lehtinen (1982) argued that service quality must be assessed in its two aspects: (1) the service delivery process and (2) the results of the service. When it comes to service quality, we cannot fail to mention the great contribution of Parasuraman et al. (1985, 1988, 1991). Parasuraman et al. (1988: 17) defined service quality as "the degree of difference between consumer's expectations of the service and their perception of the service's results". 


\section{FACTORS AFFECTING THE SATISFACTION OF BUSINESSES}

SERVQUAL is an internationally known technique used for measuring and managing service quality. When its core idea was first published by three researchers (Parasuraman et al.) back in 1985, the next series of studies by the same three scholars continued with additional research and was published later as a series of publications (Parasuraman et al., 1985; 1986 ... and Zeithaml et al., 2003 ...).

\section{Overview of online tax returns as a service}

Online filing of tax returns means that taxpayers can file tax returns on their computers and send them to tax authorities directly over the Internet, without having to send them by post or to submit papers to the tax agency in person. This is a form of electronic transaction between taxpayers and tax authorities, as prescribed by Circular 180/2010 / TT-BTC as of November 10, 2010 of the Ministry of Finance, VN.

The online tax declaration here is understood as a form of an Internet transaction between the taxpayer and the tax authority which is saving time for the taxpayer and is licensed by the tax law. The method of online tax declaration is quite fast and simple as compared to the previously used form of direct tax declaration. With this newer form of tax declaration, the taxpayer only needs to prepare tax returns on their computer, and the next step is to use a device with a digital signature to confirm and sign the declaration.

\section{Online public services and satisfaction with them}

The immense advancement of information and communication technologies along with their deployment in the public sector have played a key role in the government's effort to implement public sector reforms (Yong \& Koon, 2003). Some scholars believe that the use of information technologies in the public sector is the second revolution in public management. Information and communication technologies seek to transform not only the way public services are delivered, but also the fundamental relationship between the government and its citizens.

However, there are others who see online public services as a sub-group which is only partially and indirectly promoting the public sector reform (Yong \& Koon, 2003). In any case, the goal of online public services is to improve both efficiency and efficacy of the public sector in part of their services provision (Criado et al., 2002).

The availability of online public services is a natural evolution of the service delivery method as a response to changes in the economy as a whole and society overall. Like any other concept of management and practice in public administration, the concept of online public services has roots in the private sector's adoption of e-commerce. Therefore, the shift to online public services is characterized by the transfer of government-centric public services to a more proactive and responsive citizen system, where government information and services are provided online through the use of related technologies.

Furthermore, unlike conventional service delivery systems, online public services are non-decentralized, non-linear and available 24 hours a day, seven days a week. In such a way, people get convenient information and services, any time and in any location.

Imbalances in the online public services initiatives in the developing countries are related to infrastructure, institutional, financial and regulatory barriers. However, as governments see the potential benefits of adopting online public services, the developing countries are taking concerted efforts to launch and develop more of online public services. As a result, today, all 193 United Nations member states have launched some sort of online 
public service initiatives and are in the stages of online service delivery. This common trend is making online public services a truly global phenomenon. Electronic services have three main characteristics:

- This service can be accessed through the Internet or other electronic networks.

- This service is consumed directly or indirectly through the Internet or other electronic networks.

- There may be a fee charged for using electronic services (for example, a surcharge when one is buying tickets for a movie online). However, this usually does not happen in cases when electronic services are provided by the Government or the related authorities.

Electronic services differ from traditional goods and services due to the following four characteristics: intangibility, heterogeneity, self-service, non-contention.

\section{Factors affecting satisfaction with online public services}

\section{Information and system quality}

Information quality is usually understood as the ability to provide users with new, accurate, clear and understandable information (Aldin et al., 2006). According to DeLone and McLean (2003-2004), information quality refers to such issues as relevance, timeliness and accuracy of information, which are evaluated based on the output quality of the system. In the context of e-commerce, provision of information plays on various websites is of vital importance (McKinney et al., 2002).

System quality is the ability of the e-government system to provide users with accurate, reliable, relevant and understandable information. System quality in the Internet environment measures the characteristics that customers expect from an e-commerce system (DeLone \& McLean, 2003, 2004).

Helpfulness/usefulness

Usefulness is typically understood as productivity and performance as related to work/operations (Davis, 1989). In the corporate environment, usefulness in relation to business leaders and employees is reflected through performance and progress of the direct work.

\section{Time efficiency}

Efficiency can be defined as a user's perception of the time and efforts spent on buying or using a service. Efficiency refers to the accuracy and completeness thanks to which a user can more easily achieve a specific goal, better output, reduced time, etc. Efficient service can be defined as consumer perception of the relative time and effort spent on purchasing a product or using a service.

\section{Confidentiality of information and transactions}

One of the most important aspects in e-commerce is the concern about information security. The use of online services through the network environment can become an additional threat to security due to potential cyber attacks, shutdown of corporate computers/networks, data theft, malicious software, file corruption and the like. Cronin \&Taylor (1992) additionally described a number of issues such as censorship and security that could also hinder proper communication between individual taxpayers and the related authorities.

Support service / customer service

Support services generally refer to the help provided to assist users in finding the needed information or in their transactions. This help may include user-friendly guidelines, 


\section{FACTORS AFFECTING THE SATISFACTION OF BUSINESSES}

help pages and frequently asked questions within the websites as well as the availability of appropriate contact information. Individual consultations can be provided via e-mail or online chats or through more traditional channels such as telephone, fax or even paper postal channel (Anwer et al., 2016).

\section{Trust in tax authorities}

Trust is primarily based as a promise made by an individual or a group (Rotter, 1971). Studying trust we always need to keep in mind the differences in the experience of different individuals. Positive and negative experiences of each individual will create different personal expectations when using products or services (Rotter, 1971).

Table 2 - Summary of scales used by researchers

(Source: Summarized by the authors)

\begin{tabular}{|l|l|}
\hline Information and system quality & Pinho et al. (2008) \\
\hline Helpful awareness & Anwer et al. (2016); Pinho et al. (2008) \\
\hline Confidentiality of information and transactions & Anwer et al. (2016) \\
\hline Time efficiency & McKinney et al. (2002) \\
\hline Trust in tax authorities & Parasuraman et al. (2005) \\
\hline Support service / customer service & Anwer et al. (2016) \\
\hline
\end{tabular}

\section{Proposed research hypotheses}

H1: Information and system quality have positive impact on satisfaction.

H2: Helpful awareness has a positive impact on satisfaction.

H3: Confidentiality of information and transactions has a positive impact on satisfaction.

H4: Time efficiency has a positive impact on satisfaction.

H5: Trust in tax authorities has a positive impact on satisfaction.

H6: Support / customer service has a negative impact on satisfaction.

\section{Research Methods}

\section{Qualitative research}

Qualitative preliminary research has been used here to explore, adjust the model, supplement the observed variables and measure the research concepts. This research is conducted through interviews and focus group discussions to find out the most common opinions about the factors affecting people's satisfaction with the quality of online tax payment services at the Tax Department of Ho Chi Minh City. Quantitative preliminary research is used to assess the reliability of scales through Cronbach's Alpha testing method adjusted to suit the survey situation of enterprises using online tax payment services at the Tax Department, Ho Chi Minh City. 


\section{Quantitative research}

The data was collected through the questionnaires distributed at the enterprises using online tax payment services of the Ho Chi Minh City Tax Department. All data was collected during the period of $6 / 2020-8 / 2020$. The questionnaire included 33 statements, of which 30 covered the observed variables on six independent scales and four observed variables for the dependent scale of the satisfaction level of enterprises using online tax payment services.

The survey conducted in the summer months of 2020 was performed through submitting paper questionnaires directly or by emailing them to the potential respondents. There were 300 direct questionnaires distributed, a total of 298 questionnaires were collected. Nine questionnaires were removed due to inadequate information in them. Thus, at the end 289 questionnaires were used for further analysis.

Table 2 - Summary of scale test results

(Source: Authors' own calculations)

\begin{tabular}{|c|c|c|c|c|}
\hline Components & Variables & $\begin{array}{c}\text { Cronbach's } \\
\text { Alpha }\end{array}$ & $\begin{array}{c}\% \text { of } \\
\text { variance }\end{array}$ & Evaluation \\
\hline $\begin{array}{l}\text { Confidentiality of information and transactions } \\
\text { (CIT) }\end{array}$ & 5 & 0,891 & & \\
\hline Time efficiency (TE) & 5 & 0,897 & \multirow{5}{*}{68,280} & \multirow{7}{*}{ Qualified } \\
\hline Information and system quality (ISQ) & 5 & 0,855 & & \\
\hline Trust in tax authorities (TIT) & 4 & 0,809 & & \\
\hline Helpful awareness (HA) & 5 & 0,841 & & \\
\hline Support service / customer service (SS) & 5 & 0,851 & & \\
\hline Business satisfaction (BS) & 4 & 0,683 & 51,600 & \\
\hline Total & 33 & & & \\
\hline
\end{tabular}

Preliminary assessment was carried out using the scale with Cronbach's alpha reliability coefficient and the exploratory factor analysis method, and the presentation of the indices to test the appropriateness of the research model such as: F-value, $\mathrm{R}^{2}$, correlation coefficient, variance inflation factor (VIF) and test hypothesis. Then, we have tested the appropriateness of the model, building multiple regression equations and testing the hypotheses. Finally, we have checked the reliability of the scale with Cronbach's Alpha, EFA, CFA, linear regression analysis and SEM.

\section{Confirmatory Factor Analysis (CFA)}

Regarding the general suitability level, the factor analysis confirmed that this model has chi-squared statistical value of 267.285 with 214 degrees of freedom $(\mathrm{p}=0.008)$. Relative chi-squared with the degrees of freedom CMIN / df was 1,249 (<0.2). Other indicators were: GLI $=928(>0.9)$, TLI $=0.983(>0.9)$, CFI $=0.986(>0.9)$ and RMSEA = $0.029(<0.08)$. Therefore, this model is suitable for market data. This also allows us stating that there is unidirection of the observed variables. Convergence value, standard weights of the scales are $>0.5$ and statistically significant at $p<0.5$. Therefore, the scales achieve the convergent values. 
FACTORS AFFECTING THE SATISFACTION OF BUSINESSES

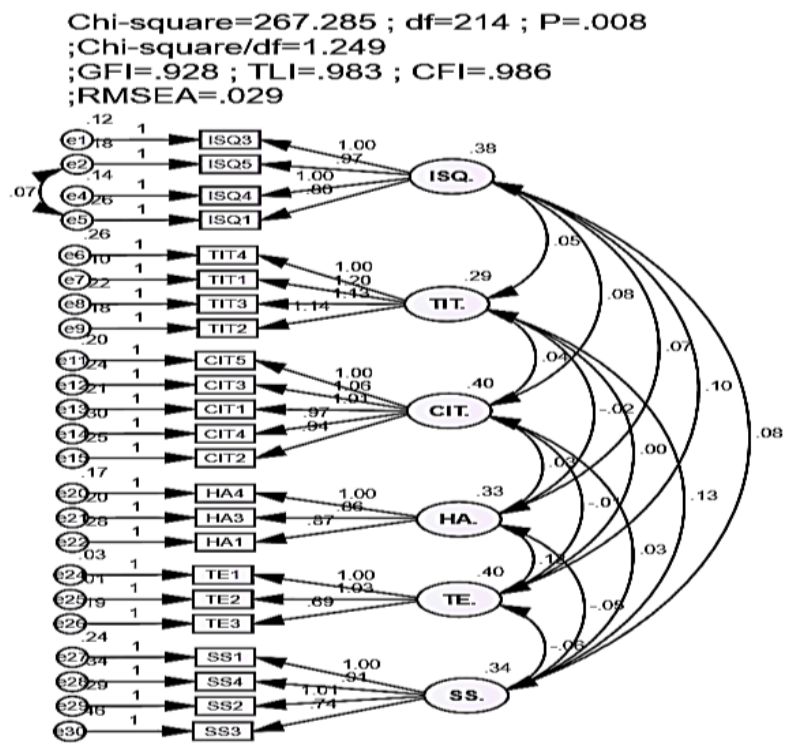

Figure 1 - CFA analysis results

(Source: Authors' own calculations)

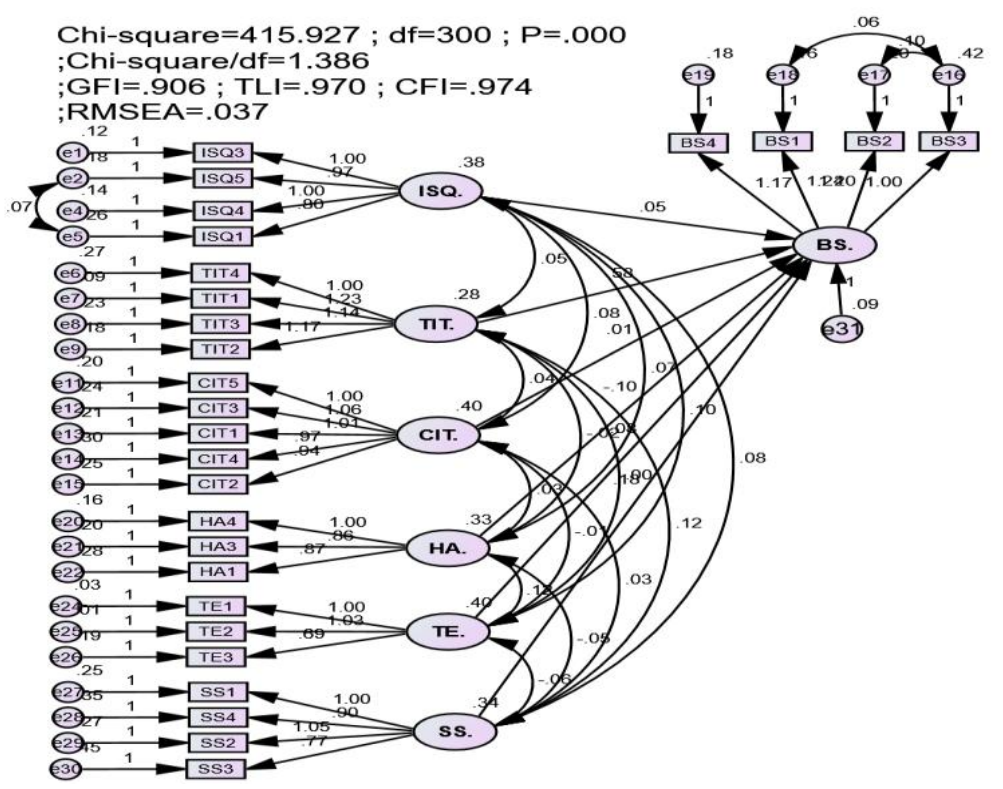

Figure 2 - SEM analysis results' visualization.

(Source: Authors' own calculations)

\section{SEM Analysis}

In this research model, there are six research concepts, and there also are six independent variables including: (1) Information and system quality, (2) Time efficiency, (3) Confidentiality of information and transactions, (4) Support service / customer service, (5) Helpful awareness, (6) Trust in tax authorities. The results show us that the linear structural model has chi-squared statistical value of 415,927 with 280 degrees of freedom $(p=0.000)$. The relative chi-squared with the degrees of freedom CMIN / df is $1.386(<0.2)$. Other 
indicators are as follows: GLI $=0.906(0.9)$, TLI $=0.970(>0.9), \mathrm{CFI}=0.974(>0.9)$ and RMSEA $=0.037(<0.08)$. Therefore, this model achieves compatibility with the market data. This means the acceptance of hypotheses H1, H2, H3, H4, H5 and H6.

\section{The influence of scale components on enterprise satisfaction}

Table 3 - Model Summary ${ }^{\mathrm{b}}$

(Source: Authors' own calculations)

\begin{tabular}{|c|c|c|c|c|c|c|c|c|c|c|}
\hline \multirow[b]{2}{*}{$\begin{array}{l}\overline{0} \\
\frac{0}{2}\end{array}$} & \multirow[b]{2}{*}{$\simeq$} & \multirow[b]{2}{*}{ 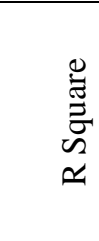 } & \multirow[b]{2}{*}{ 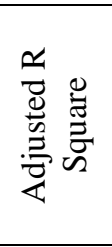 } & \multirow{2}{*}{ 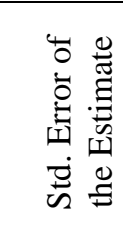 } & \multicolumn{5}{|c|}{ Change Statistics } & \multirow{2}{*}{ 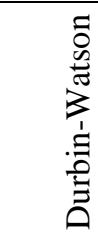 } \\
\hline & & & & & 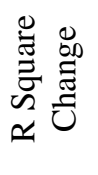 & 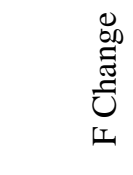 & $\bar{z}$ & $\stackrel{\mathbb{Z}}{y}$ & 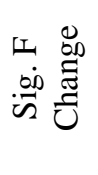 & \\
\hline 1 & $.769^{\mathrm{a}}$ & .591 & .583 & .31081 & .591 & 66.359 & 6 & 275 & .000 & 1.224 \\
\hline
\end{tabular}

a. Predictors: (Constant), CIT, HA, ISQ, TE, TIT, SS

b. Dependent Variable: BS

The linear regression results show that the coefficient of determination $\mathrm{R}^{2}$ is 0.591 and the adjusted $\mathrm{R}^{2}$ is 0.583 . This means that the model explains $58.3 \%$ of the variation depending on the satisfaction of businesses when using online tax payment services provided by the Tax Department HCM City is predetermined by the independent variables in the model. The remaining $41.7 \%$ of the variation is explained by other variables. The model also shows that the independent variables positively affect the satisfaction from using online tax payment services provided by the Department Tax in HCM at 95\% confidence. This means that the more favorable the factors are, the more satisfied businesses are when using this service.

Table 4 - ANOVA ${ }^{\mathrm{ab}}$

(Source: Authors' own calculations)

\begin{tabular}{|c|c|c|c|c|c|c|}
\hline \multicolumn{2}{|c|}{ Model } & Sum of Squares & df & Mean Square & F & Sig. \\
\hline \multirow{3}{*}{1} & Regression & 38.463 & 6 & 6.410 & 66.359 & $.000 \mathrm{~b}$ \\
\cline { 2 - 7 } & Residual & 26.566 & 275 & .097 & & \\
\cline { 2 - 7 } & Total & 65.029 & 281 & & & \\
\hline
\end{tabular}

a. Dependent Variable: BS

b. Predictors: (Constant), CIT, HA, ISQ, TE, TIT, SS

F-statistic value is 66.359 as calculated from $\mathrm{R}^{2}$ value of the full model, at the significance level of $\mathrm{Sig}=0.000$. We have also checked the correlation phenomenon by means of Durbin-Watson coefficient $(1<1.224<3)$. Our linear regression model is consistent with the research model and the data. 
FACTORS AFFECTING THE SATISFACTION OF BUSINESSES

Table 5 - Parameters of each variable in the regression equation (Source: Authors' own calculations)

\begin{tabular}{|c|c|c|c|c|c|c|c|c|}
\hline \multirow{2}{*}{$\frac{\bar{D}}{8}$} & \multirow[t]{2}{*}{$\begin{array}{l}\text { Unstandardized } \\
\text { Coefficients }\end{array}$} & \multicolumn{2}{|c|}{$\begin{array}{l}\text { Standardized } \\
\text { Coefficients }\end{array}$} & \multirow{2}{*}{$\begin{array}{c}\mathrm{t} \\
\text { Beta }\end{array}$} & \multirow[t]{2}{*}{ Sig. } & \multirow{2}{*}{$\frac{\bar{\theta}}{8}$} & \multicolumn{2}{|c|}{$\begin{array}{l}\text { Collinearity } \\
\text { Statistics }\end{array}$} \\
\hline & & B & $\begin{array}{l}\text { Std. } \\
\text { Error }\end{array}$ & & & & $\begin{array}{l}\text { Tole- } \\
\text { rance }\end{array}$ & VIF \\
\hline \multirow{7}{*}{1} & Constant & 0.259 & 0.184 & & 1.406 & 0,161 & & \\
\hline & $\begin{array}{l}\text { Information and system } \\
\text { quality }\end{array}$ & 0.134 & 0.036 & 0.157 & 3.685 & 0.000 & .821 & 1.218 \\
\hline & Helpful awareness & 0.156 & 0.039 & 0.180 & 4.021 & 0.000 & .753 & 1.328 \\
\hline & Trust in tax authorities & 0.276 & 0.039 & 0.321 & 7.059 & 0.000 & .694 & 1.441 \\
\hline & Time efficiency & 0.113 & 0.028 & 0.171 & 4.060 & 0.000 & .719 & 1.392 \\
\hline & $\begin{array}{l}\text { Confidentiality of } \\
\text { information and } \\
\text { transactions }\end{array}$ & 0.176 & 0.035 & 0.226 & 5.097 & 0.000 & .742 & 1.348 \\
\hline & $\begin{array}{l}\text { Support service/customer } \\
\text { service }\end{array}$ & 0.110 & 0.037 & 0.138 & 2.973 & 0.003 & .841 & 1.189 \\
\hline
\end{tabular}

a. Dependent Variable: BS

Table 5 above shows that there are six factors affecting satisfaction, all have a positive impact (positive coefficient) on the satisfaction level of businesses when using online tax payment services provided by the Tax Department of HCM City with the significant levels $\mathrm{Sig}=0.000-0003$ in all six variables being $<0.05$. Table 5 also shows that the variable tolerances (acceptability) are quite high, from 0.694 and above, and the VIF coefficient of all six factors is less than 2, meaning that no multicollinearity phenomenon occurs between the independent factors in question.

The regression equation for the variables with the coefficients can be presented in the following form: where:

$$
\mathrm{F} 1=0.259+0.134 \mathrm{H} 1+0.156 \mathrm{H} 2+0.276 \mathrm{H} 3+0.113 \mathrm{H} 4+0.176 \mathrm{H} 5+0.110 \mathrm{H} 6+\varepsilon 1,
$$

F1: The satisfaction of businesses when using online tax payment services provided by the City Tax Department of HCM (also BS in this study)

H1: Information and system quality (ISQ)

H2: Helpful awareness (HA)

H3: Trust in tax authorities (TIT)

H4: Time efficiency (TE)

H5: Confidentiality of information and transactions (CIT)

H6: Support service / customer service (SS)

\section{The results of the theoretical model testing}

If the absolute value of beta coefficient is larger, then a factor has a strong impact on the satisfaction of businesses when using online tax payment services provided by the City Tax Department in HCM. Looking at Table 5, we can see that the factor of Confidentiality of information and transactions has the strongest impact on satisfaction because its Beta $=0.321$ with Sig. $=0.000<0.05$. Trust in tax authorities and Helpful awareness have the impact 
because there are beta coefficients $=0,226$ and 0.180 with Sig. $=0.000<0.05$. Next goes the Time Efficiency, Information and system quality coefficients with their Betas being $=0.171$ and 0.157, respectively, with Sig. $=0,000<0.05$. Finally, Support Services / Customer Service has the Beta coefficient $=0.138$ with Sig. $=0.003<0,05$ which is the smallest of the Beta coefficients in our study.

From the above analysis, we can conclude that the theoretical model is suitable for the research data and we accept the research hypotheses $\mathrm{H} 1, \mathrm{H} 2, \mathrm{H} 3, \mathrm{H} 4 \mathrm{H} 5$ and $\mathrm{H} 6$.

\section{Discussing the results and further research directions}

The confidentiality of information and transactions has a positive impact on business satisfaction with online tax service

According to the research results, this is the criterion that has the strongest impact (beta $=0.321$ ) on the satisfaction of users with online tax services. The results of this study differ from those obtained in the study by Pinho et al. (2008) concerning the level of impact on satisfaction. In (Pinho et al., 2008), the level of data safety and security was shown to have an impact on satisfaction, but the level of impact was low. However, the authors also emphasize that confidentiality should be maintained to the maximum extent possible. The reason for this difference is that in Vietnam, the application of online services through the network environment is still a new phenomenon, thus, the infrastructure is still inadequate and needs further development. Therefore, taxpayers still have some concerns about data safety and security of the online taxation system.

\section{Trust the tax authority has a positive effect on satisfaction with online tax service}

According to research results, this is the second most powerful criterion (beta $=0.226$ ) on the satisfaction with online tax services. Trust in tax authorities, including trust in tax authorities' websites, demonstrates the confidence of businesses when making electronic tax declarations and further tax payments online.

Helpful awareness has a positive impact on satisfaction with online tax service

According to our research results, this is a criterion that has a relatively strong impact (beta $=0.180$ ) on the satisfaction of businesses with online tax services. The advantage of the electronic tax payment service is that through the web portal of the tax authority, an enterprise can submit tax forms and pay money 24/7/365 and from anywhere, provided there is Internet connection. Thus, businesses no longer have to depend on working hours of transaction counters at banks or other institutions. In case of online tax payment, the bank will send the transaction confirmation right after the electronic tax return is delivered online, in real time.

\section{Time efficiency has a positive impact on business satisfaction}

According to our research results, this is a criterion with a quite high impact (beta = 0.171 ) on the satisfaction with online tax services. The efficiency showed in the provision of online tax services means saving time, money and becoming more efficient in data processing overall. Thus, the use of online tax services will make businesses feel more satisfied since these services help businesses save their valuable time and resources. 


\section{FACTORS AFFECTING THE SATISFACTION OF BUSINESSES}

According to the 2019 Business Environment report released by the World Bank, Vietnam's tax compliance time is now 351 hours on average. Of these 351 hours, 334 hours are spent in data calculations and forms' preparation. The time for filing and paying taxes is only 17 hours. Clearly, the application of the online tax declaration and payment helps businesses save time significantly. This result is also in agreement with Pinho et al. (2008) and Anwer et al. (2016).

\section{Information and system quality have a positive impact on business satisfaction}

According to our research results, this is the criterion with the fifth strongest impact (beta $=0.157$ ) on the satisfaction with online tax services. Customer satisfaction is a general concept that shows people's satisfaction when consuming a service, while service quality focuses only on the specific components of the service (Zeithaml \& Bitner, 2000).

Although there is a correlation between service quality and satisfaction, there is not sufficient research focusing on verifying the level of interpretation of service quality components in their relation to satisfaction, especially for each specific service sector.

\section{Customer service / support has a negative impact on business satisfaction}

According to our research results, this is the criterion with the lowest impact (beta = 0.138) on the satisfaction with online tax services. Therefore, in our opinion, tax authorities should get a better understanding of the needs of enterprises through dialogue. Distributing questionnaires is one of the ways to get useful data and then to classify and choose measures and forms of support.

The Department of Taxation usually collects statistical data on the number of support services related to tax payment consulting provided to businesses over the years. This allows classifying those services according to certain criteria. At the same time, surveys would provide a better picture about the actual situation with the quality of service delivery. Combining survey data with the analysis of the tax law implementation would help to proactively plan, support and advise on timely tax payments and tax compliance overall.

\section{Limitations of the topic and directions for further research}

The major limitation of this study is that it was only implemented on the example of one City Tax Department, in one city - HCM. Therefore, perceptions and attitudes of other Vietnamese taxpayers in other localities can be very different. Generalization of useful data would be possible if such or similar surveyors would be implemented for other 24 District Tax Departments. Later on, such surveys could be also carried out at Tax Departments of 63 provinces and cities across Vietnam.

At the same time we need to mention, on a final note, that our study has not explored in depth other qualitative variables such as taxpayer groups, types of business and so on. Thus, potential differences between them have been disregarded here.

\section{References:}

Abhichandani, T. \& Horan, T.A. (2006). Toward A New Evaluation Model of E-Government Satisfaction: Results of Structural Equation Modeling. Available online at: https://www.researchgate.net/publication/220891056_Toward_A_New_Evaluation_Model_of_ E-Government_Satisfaction_Results_of_Structural_Equation_Modeling. 
Anwer, M.A., Esichaikul, V., Rehman, M. \& Anjum, M. (2016). E-government services evaluation from citizen satisfaction perspective: A case of Afghanistan. Transforming Government: People, Process and Policy, 10(1), 139-167.

Barnes, S. J. \& Vidgen, R. T. (2006). Data triangulation and web quality metrics: a case study in egovernment. Information and Management, 43 (6), 767-777.

Criado, J. I, Hughes, O. \& Teicher, J. (2002). E-Government and managerialism: a second revolution in public management. Proceedings of the 6th International Research Symposium on Public Management, University of Edinburgh, April 8-10.

Cronin, J. J. \& Taylor, S. A. (1992). Measuring service quality: a reexamination and extension. Journal of Marketing, 6, 55-68.

Davis, F. D. (1989). Perceived usefulness, perceived ease of use, and user acceptance of information technology. MIS Quarterly, 13(3), 319-340.

DeLone, W.H. \& McLean, E.R. (2004). Measuring e-commerce success: applying the DeLone \& McLean Information systems success mode. International Journal of Electronic Commerce, $9(1), 31-47$.

Haywood-Farmer, J. (1988). A conceptual model of service quality. International Journal of Operations and Production Management, 8(6), 19-29.

Lehtinen, U \& Lehtinen, J. (1982). Service Quality: A Study of Quality Dimensions, Working Paper, Service Management Institute, Helsinki, Finland.

McKinney V., Yoon K., \& Zahedi F. M. (2002). The measurement of web-customer satisfaction: an expectation and disconfirmation approach. Information Systems Research, 13(3), 296-315.

Parasuraman, A., Zeithaml, V. A. \& Berry, L. (1985). A conceptual model of service quality and its implications for future research. Journal of Marketing, 49 (3), 41-50.

Parasuraman, A., Zeithaml, V. \& Berry, L. (1988). SERVQUAL: a multiple-item scale for measuring consumer perceptions of service quality. Journal of Retailing, 64 (1), 12-40.

Parasuraman A., Zeithaml V.A. \& Malhotra A. (2005). E-SQual: A multiple-item scales for assessing electronic service quality. Journal of Service Research, 7(3), 213-233.

Pinho, J.C. \& Macedo, I.M. (2008). Examining the antecedents and consequences of online satisfaction within the public sector: The case of taxation services. Transforming Government: People, Process and Policy, 2(3), 177-193.

Rotter, L.B. (1971). Generalized expectations for interpersonal trust. American Psychologist, 26(5), 443-452.

Yong, J.S.L. \& Koon, L.H. (2003). E-Government: Enabling Public Sector Reform. E-government in Asia: Enabling Public Service Innovation in the 21st Century, Yong, JSL (ed.), Times Media: 3-21.

Zeithaml, V.A., Bitner, M.J. \& Gremler, D.D. (2006). Services Marketing: integrating customer focus across the firm. McGraw-Hill, Irwin.

Paper submitted

Paper accepted for publishing

Paper published online
O8 October 2020

13 November 2020

31 January 2021 